\title{
Simulating an ocean wave power plant with Homer
}

\author{
Jones S. Silva, Alexandre Beluco, Luiz Emílio B. de Almeida \\ Inst Pesquisas Hidráulicas, Univ Fed Rio Grande do Sul, Porto Alegre, Brazil.
}

\begin{abstract}
In recent years, renewable resources have become an important alternative to increase the capacity of power generation. Among the resources available, the energy in the oceans have attracted more interest and experiencing a period of strong development. Wave energy is the one that is currently closest to reach a stage of technical and economic maturity. In this process, computational tools to facilitate evaluation of the feasibility of power systems including ocean wave power plants are critical. This paper presents the use of software Homer, version Legacy, for evaluation of technical and economic feasibility of hybrid energy systems including contribution of wave energy. Homer is a software designed for the optimization of micro power systems that has a very broad spectrum of applications. A case study in southern Brazil is presented, studying the inclusion of an ocean wave power plant in a wind biodiesel hybrid system and showing the functionality of Homer for this purpose.
\end{abstract}

Copyright $(2014$ International Energy and Environment Foundation - All rights reserved.

Keywords: Ocean energy; Ocean wave energy; Computational simulation; Feasibility study; Software Homer; Southern Brazil.

\section{Introduction}

Amid a global economic crisis, it still remains necessary to find alternatives to fossil fuels that have technical and economic capabilities for providing energy supplies that are currently needed. In some places, renewable resources are the only available solution rather than a solution environmentally desirable.

Among the resources available, the energy in the oceans have been experiencing in recent years a strong and fast ripening process. Specifically wave energy must shortly reach its technical and economic maturity. There are currently a wide range of designs that allow the conversion of wave energy into electricity.

There is a lot of designs and projects to convert wave energy into electricity. Some of these projects are closer to viability than others. Each year several new developments arise, just as many others are being abandoned [1,2]. Environmental issues involving the use of wave energy are permanent [3] and should always be seen as a challenge.

In this process, it is important that computational tools can be applied to expedite the process of evaluating technical and economic feasibility for a given power plant. Tools that also allow the study of its insertion in hybrid systems with other resources in most advanced technological stages and the determination of specific costs that must be achieved.

Among the computational tools available for assessment of the feasibility of energy systems, Homer [4, 5 ] is designed for optimization of micro power systems that presents a wide and interesting range of applications. Among the energy conversion equipment based on renewables, except those that use fuels, 
Homer simulates hydro power plants, wind turbines and PV modules.

Above all, Homer is convenient and fast to be programmed, simple to be learned [6] and, even with some limitations, very friendly with regard to the evaluation of results. The version [7] that is available free of charge is sufficient for most applications.

Homer is a very user friendly software and beyond the feasibility assessment of power systems, also allows to study other aspects such as operational details related to failures in the power supply or details of the rules established for energy dispatches

There are several designs being developed for converting wave energy into electricity and the power plants can be installed close to the beach as far away from the coast [2]. Wave energy has a variability that can be compared with wind energy and its use has impact on the system in which it will be connected [8]. Operating in conjunction with reversible hydro power plants can mitigate these effects [9] increasing the capacity factor of plants based on these renewables.

The variability of the energy available in the ocean waves, as well as the variability of other renewable resources may be alleviated if the resources involved present energetic complementarity in time [10, 11]. When one of the energy resources is in its period of minimum availability, the other has higher availability, ensuring the supply of energy to consumers. Wave energy and wind energy are probably not complementary to each other, but can be exploited in complementarity with other renewables.

This technical note shows how Homer can be used to simulate an ocean wave power plant and describes a case study in southern Brazil in which the inclusion of an ocean wave power plant in a wind biodiesel hybrid system is simulated. As suggested in this work, Homer can be used for any design of equipment for energy conversion, with the focus always on the evaluation of the economic feasibility. The case study is not exhaustive and only shows some results.

\section{Energy from ocean waves}

The power $\mathrm{P}[\mathrm{W} / \mathrm{m}]$ available per unit of length of wave front is given by equation (1) [12], where $\rho$ $[\mathrm{kg} / \mathrm{m} 3]$ is the density of sea water, $\mathrm{g}[\mathrm{m} / \mathrm{s} 2]$ is the acceleration due to gravity, $\mathrm{Hs}[\mathrm{m}]$ is the significant wave height and $\mathrm{Te}[\mathrm{s}]$ is the wave period.

$$
\mathrm{P}=\frac{\rho \mathrm{g}^{2}}{64 \pi} \mathrm{H}_{\mathrm{S}}^{2} \mathrm{~T}_{\mathrm{e}}
$$

The available energy in ocean waves is presented a more thoroughly manner by reference [13], which also discusses the estimation of energetic potential. Reference [14] discusses the estimation of potential in conditions of scarce data.

For a real plant with lenght $\mathrm{L}[\mathrm{m}]$ and an overall performance of the plant equal to $\eta$ wav [1], the power Pwav [W] which may be available will be given by equation (2). Most devices currently in development involve performances between $30 \%$ and $40 \%[1,2]$.

$P_{\text {wav }}=P L \eta_{\text {wav }}$

Substituting (1) into (2), the power Pwav can be written as shown in (3).

$P_{\text {wav }}=\frac{\rho g^{2}}{64 \pi} H_{s}^{2} T_{e} L \eta_{\text {wav }}$

This equation will be used to build the model for the description of a wave power plant.

\section{Homer, the micropower optimization model}

The software HOMER (2009), The Micropower Optimization Model, was developed by National Renewable Energy Laboratory (NREL) and is available for universal access in its version 2.68 beta. HOMER simulates a system for power generation over the time period considered in the project, which may be several years, at intervals of 60 minutes, presenting the results for a period of one year $[4,5]$.

HOMER includes models for simulation of micro hydro power plants, wind turbines and PV modules, in addition to fuel based generators. The software must be supplied with technical specifications of the 
generator sets, the availability of energy resources and characteristics of consumed fuels. The systems simulated by Homer also include various types of loads and some alternatives for energy storage. Homer also has full capacity to studies including the production and consumption of hydrogen.

Figure 1 shows the alternatives offered by HOMER for the simulation of energy systems. HOMER can simulate systems with multiple generators in parallel, with up to ten different designs of gen sets, up to ten different models of batteries. HOMER can also simulate the connection with interconnected energy systems.

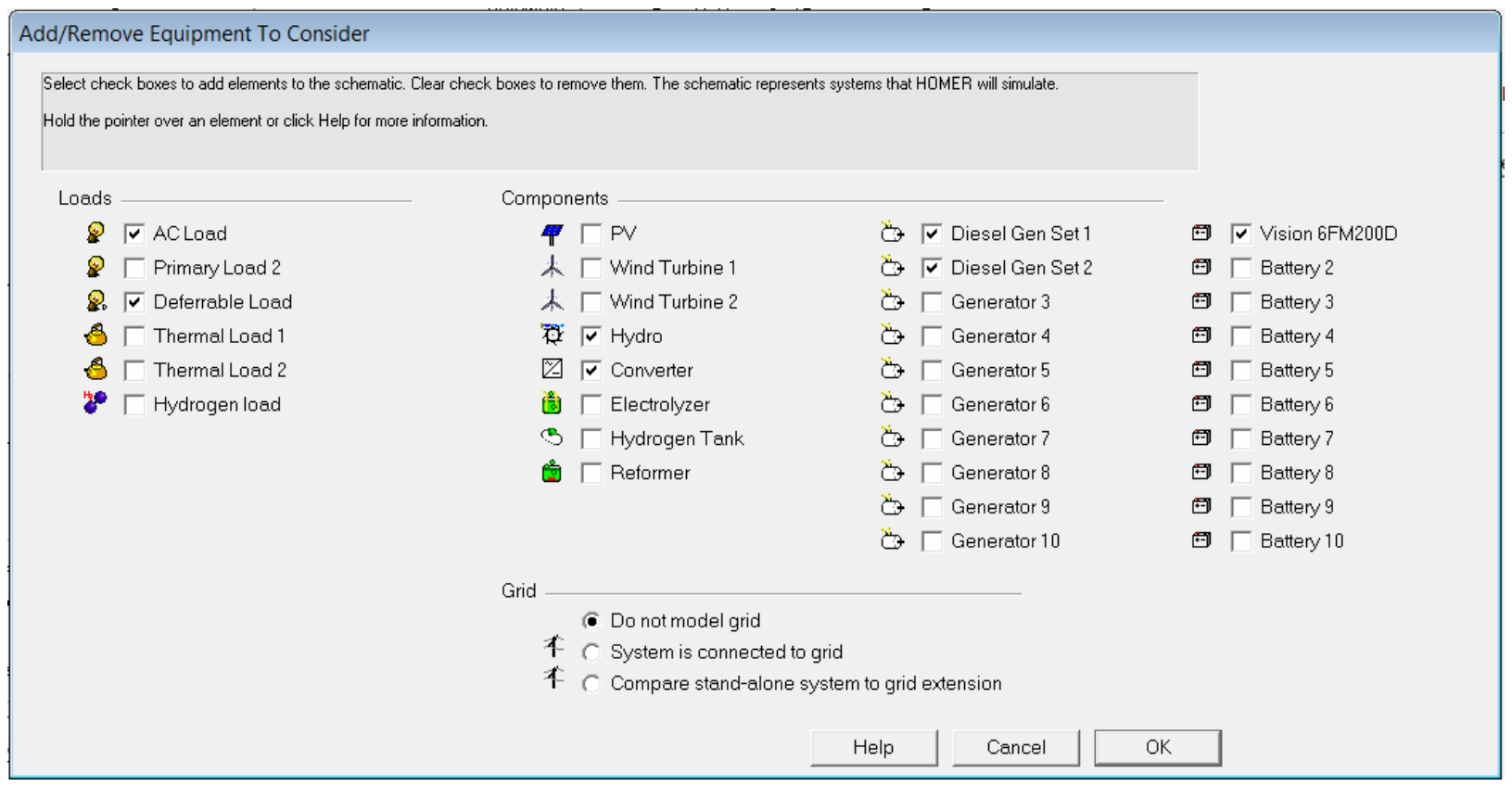

Figure 1. Alternatives offered by HOMER for simulation of hybrid energy systems

The intention of this work is the simulation of an ocean wave power plant, not currently contemplated by HOMER. In the absence of a specific model, then the solution will be obtained improvising with some of the available models.

The most appropriate choice is the model of hydroelectric plants. It should be emphasized however that available height and design flow rate, in the case of simulation of an ocean wave power plant, lose their meaning and become new model parameters.

\section{Homer's model for micro hydro power plants}

The power in a hydroelectric plant, Phyd [W], is given by equation (4), where $\gamma\left[\mathrm{N} / \mathrm{m}^{3}\right]$ is the specific weight of sea water, $\mathrm{Q}\left[\mathrm{m}^{3} / \mathrm{s}\right]$ is the flow rate, $\mathrm{H}[\mathrm{m}]$ is the available head and $\eta_{\text {hyd }}[1]$ is the total performance of the power plant.

$P_{\text {hyd }}=\gamma \mathrm{QH} \eta_{\text {hyd }}$

The HOMER simulates a "run-of-river" plant, with constant available head [4]. The Figure 2 shows the information that must be supplied to the power plant model used by Homer.

Among the specifications of the turbine, the available head $[\mathrm{m}]$, the design flow rate $[\mathrm{L} / \mathrm{s}]$, minimum and maximum flow ratios, as a percentage of the design flow rate, and efficiency.

For Economic values, capital cost, replacement cost, operation and maintenance cost per year and life time in years.

There is a module for calculating the pressure drop in the pipeline, depending on the pipe length, pipe diameter and pipe roughness.

At the end, there is still the option to include a hydro power plant in all simulated systems or to include only those systems for which prove feasible. 


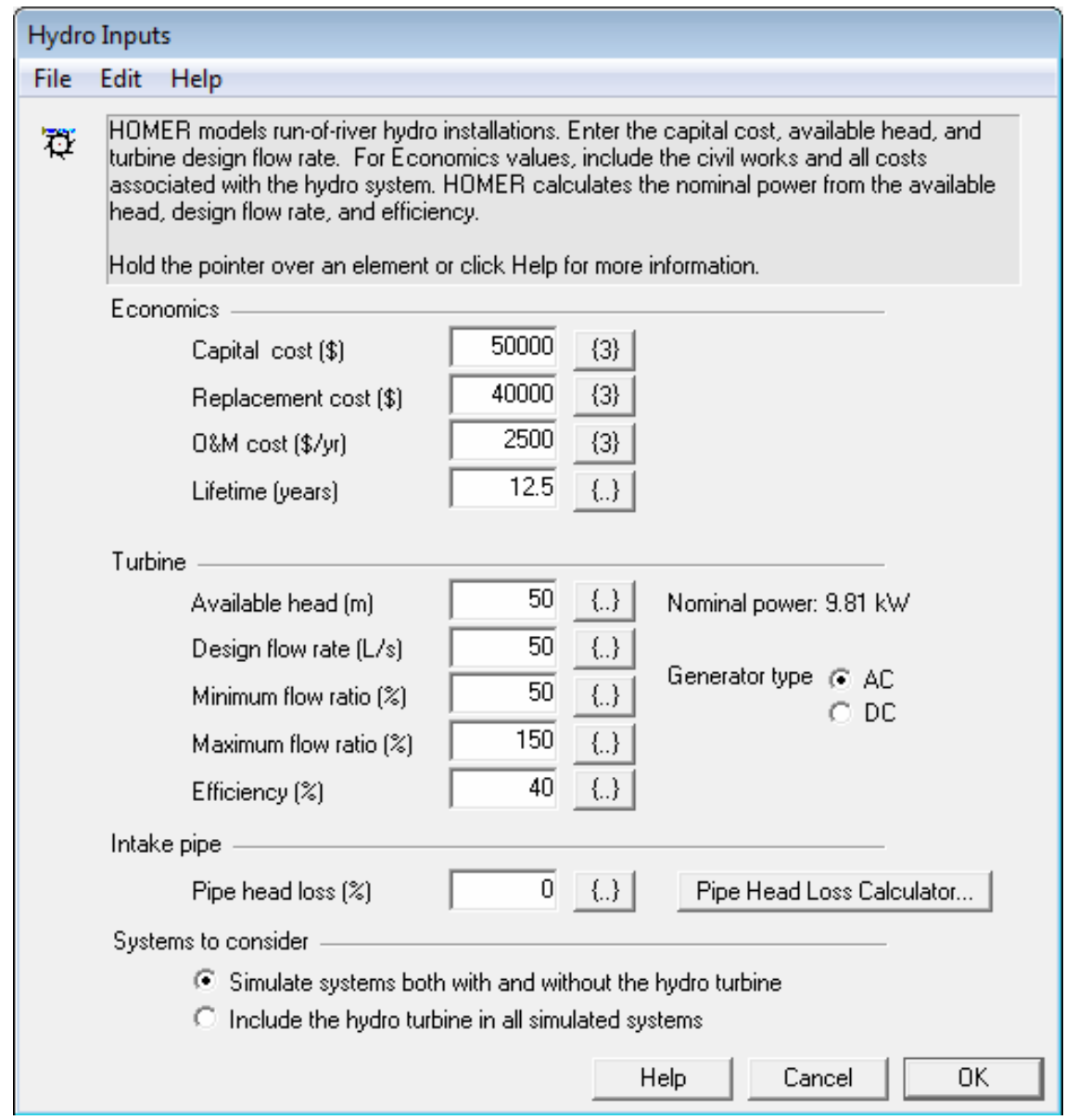

Figure 2. Parameters for the HOMER's model of a micro hydro power plant

\section{Adaptation to simulate ocean wave power plants}

As Homer does not offer a model that reproduces a wave power plant, it will be necessary to perform this simulation with some of the available models. The most appropriate choice for the characteristics of the adopted model is the model that reproduces hydro electric power plants.

Adjustments will be made simply by determining which values should be entered as height and stream flow in the model used to describe a hydroelectric power plant and will be adapted to describe an ocean wave power plant. Equation (5) shows what will be done.

$P_{\text {hyd }}=P_{\text {wav }}$

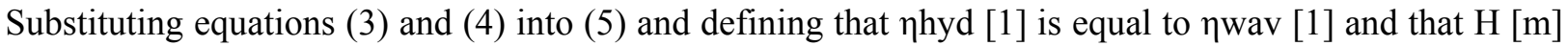
is equal to $\mathrm{L}[\mathrm{m}]$, it is possible to write (6).

$$
\mathrm{Q}=\frac{\mathrm{g}}{64 \pi} \mathrm{H}_{\mathrm{s}}^{2} \mathrm{~T}_{\mathrm{e}}
$$

The flow rate then takes a new interpretation. Since ( $[\mathrm{m} 3 / \mathrm{s}]$ can also be expressed by (7).

$$
Q=(0.05) H_{s}^{2} T_{e}
$$

The flow rate can also be determined by the other side, from the data of available wave energy. Thus, simply divide the available power per meter of wave front by the specific weight of water, as shown in (8). If $\mathrm{H}$ is assigned to a constant value, it should appear in the denominator of (8). 


$$
\mathrm{Q}=\frac{1}{\gamma} \frac{\mathrm{P}_{\mathrm{wav}}}{\mathrm{L} \eta_{\mathrm{wav}}}
$$

\section{An application example}

The model was developed to study the insertion of a wave power plant in a micro power hybrid system situated not far from the coast. Since there are no commercially available technologies, the study was aimed to determine minimum cost to make it viable. The results can serve as a parameter for building a power plant or to purchase equipment.

The application example is a wind diesel hybrid system located on a small farm in the municipality of Mostardas1, in the state of Rio Grande do Sul. This system has been the subject of a study, conducted by Ponticelli and Beluco [16] for inserting biodiesel and PV modules and will now also be considered for the use of wave energy.

The farm lies between the Atlantic Ocean and the Lagoa dos Patos, in a region of rice cultivation and livestock activities, dedicating themselves to this second activity. The hybrid system is used to supply small mechanical drives and other minor loads. The system also supplies the electrical loads of the farmhouse when the interconnected system failure, but this was not simulated in a specific way. The system is shown in Figure 3(a).

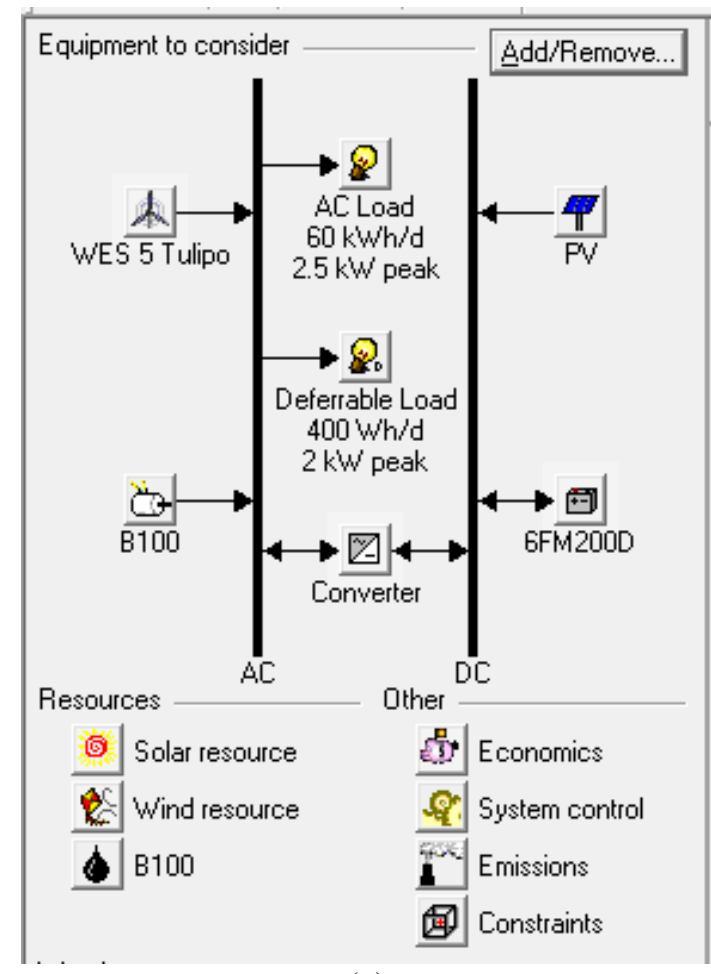

(a)

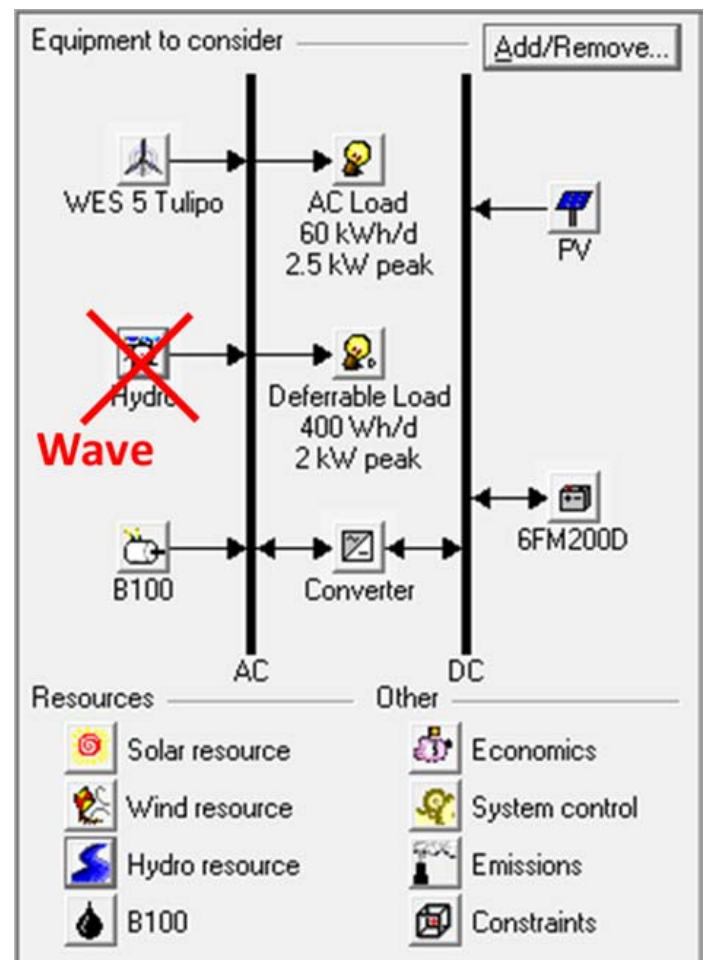

(b)

Figure 3. (a) Hybrid system of the Reference [16] and (b) hybrid system including an ocean wave power plant on the right

Loads have consumption value around $105 \mathrm{kWh}$ per day, kept constant by a control system which connects loads for heating water. There is also a water storage system, modeled on Homer as deferrable loads, with consumption of about $400 \mathrm{Wh}$ per day.

The engine generator set is Branco [17], model BD $6500 \mathrm{CF}$ with $10 \mathrm{hp}$, with $5.5 \mathrm{kVA} / 5.0 \mathrm{~kW}$ nominal power. The wind turbine WES 5 [18] was employed, with $2.5 \mathrm{~kW}$ rated with three rotor blades $5 \mathrm{~m}$ diameter, with induction generator and IGBT converter. An anemometer connected to a control system allows controlling the speed of the turbine. 
Figure 4 shows the wind speeds recorded in the first year of operation of the wind turbine, between August 2009 and July 2010. Data were obtained at 25 meters from the ground at approximately the same height as the wind turbine. Figure 5 shows the availability of solar power for the hybrid system, obtained through software Homer with NASA.

Figure 6 shows the instantaneous power in the form of waves available per meter of wave front over a year. These data were obtained with Reference [19] and correspond to the availability of energy throughout the year 1998.

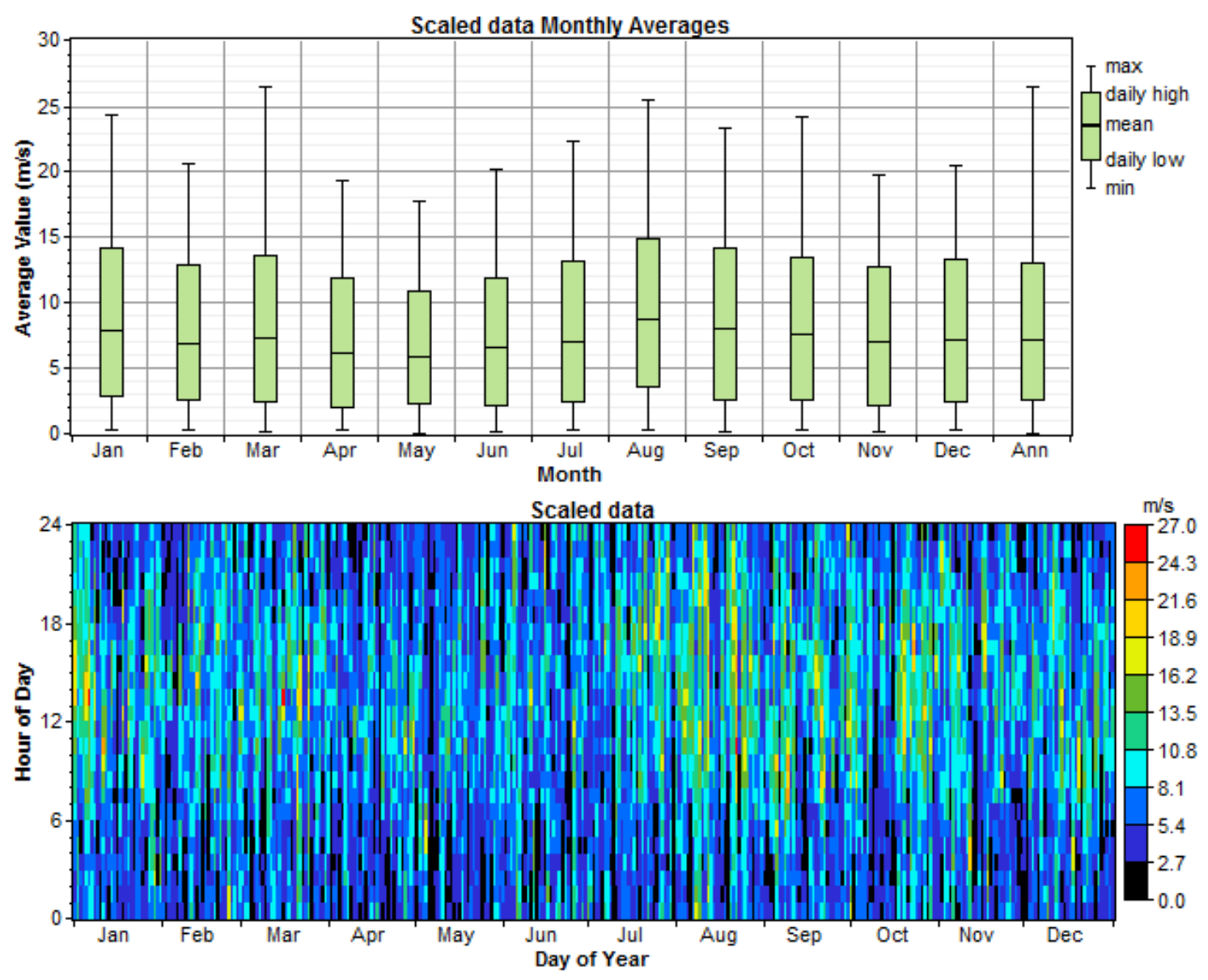

Figure 4. Wind speed data obtained in the first year of operation of the equipment

Figure 7 shows these data as used by software Homer, obtained using equation (17). These data correspond to a wave power plant with a length of 1 meter, simulated with the model of a plant with 25 meters high. The performance of the power plant is considered equal to $100 \%$ and hydraulic losses are equated to zero.

Figure 3(b) shows the hybrid system already equipped with the wave power plant. The system includes an $\mathrm{AC}$ bus and the other in DC, with the first receiving supplies of wind turbines, diesel generator and wave power plant and the second photovoltaic contribution. The electrical load is connected to the AC bus and battery bank [20] to the DC bus, with the energy flow in both directions between the two buses made possible by the converter device.

Simulations were performed for the following values of the optimization variables: $0,1,2,4$ or 8 wind turbines; $0 \mathrm{~kW}, 5 \mathrm{~kW}$ or $10 \mathrm{~kW}$ for diesel generator set; $0.00 \mathrm{~kW}, 0.20 \mathrm{~kW}, 0.40 \mathrm{~kW}, 0.80 \mathrm{~kW}, 1.20 \mathrm{~kW}$, $1.60 \mathrm{~kW}$ and $2.00 \mathrm{~kW}$ for PV array; $0.00 \mathrm{~kW}, 0.25 \mathrm{~kW}, 0.50 \mathrm{~kW}, 1.00 \mathrm{~kW}$ and $2.00 \mathrm{~kW}$ for converter capacity and $0,1,2,4$ and 8 batteries. Simulations were performed for the following values of the sensitivity inputs: $60 \mathrm{kWh} / \mathrm{d}$ for AC Load; $4 \mathrm{~m} / \mathrm{s}, 6 \mathrm{~m} / \mathrm{s} 8 \mathrm{~m} / \mathrm{s}$ or $10 \mathrm{~m} / \mathrm{s}$ for wind speed; and $0.40 \$ / \mathrm{L}$, $0.60 \$ / \mathrm{L}, 0.80 \$ / \mathrm{L}, 1.00 \$ / \mathrm{L}, 1.20 \$ / \mathrm{L}$ or $1.40 \$ / \mathrm{L}$ for pure diesel price. These simulations were repeated to $0 \mathrm{~kW}, 5 \mathrm{~kW}$ and $10 \mathrm{~kW}$ for biodiesel generator set, with $0.40 \$ / \mathrm{L}, 0.60 \$ / \mathrm{L}, 0.80 \$ / \mathrm{L}, 1.00 \$ / \mathrm{L}, 1.20$ $\$ / \mathrm{L}$ or $1.40 \$ / \mathrm{L}$ for biodiesel price. 

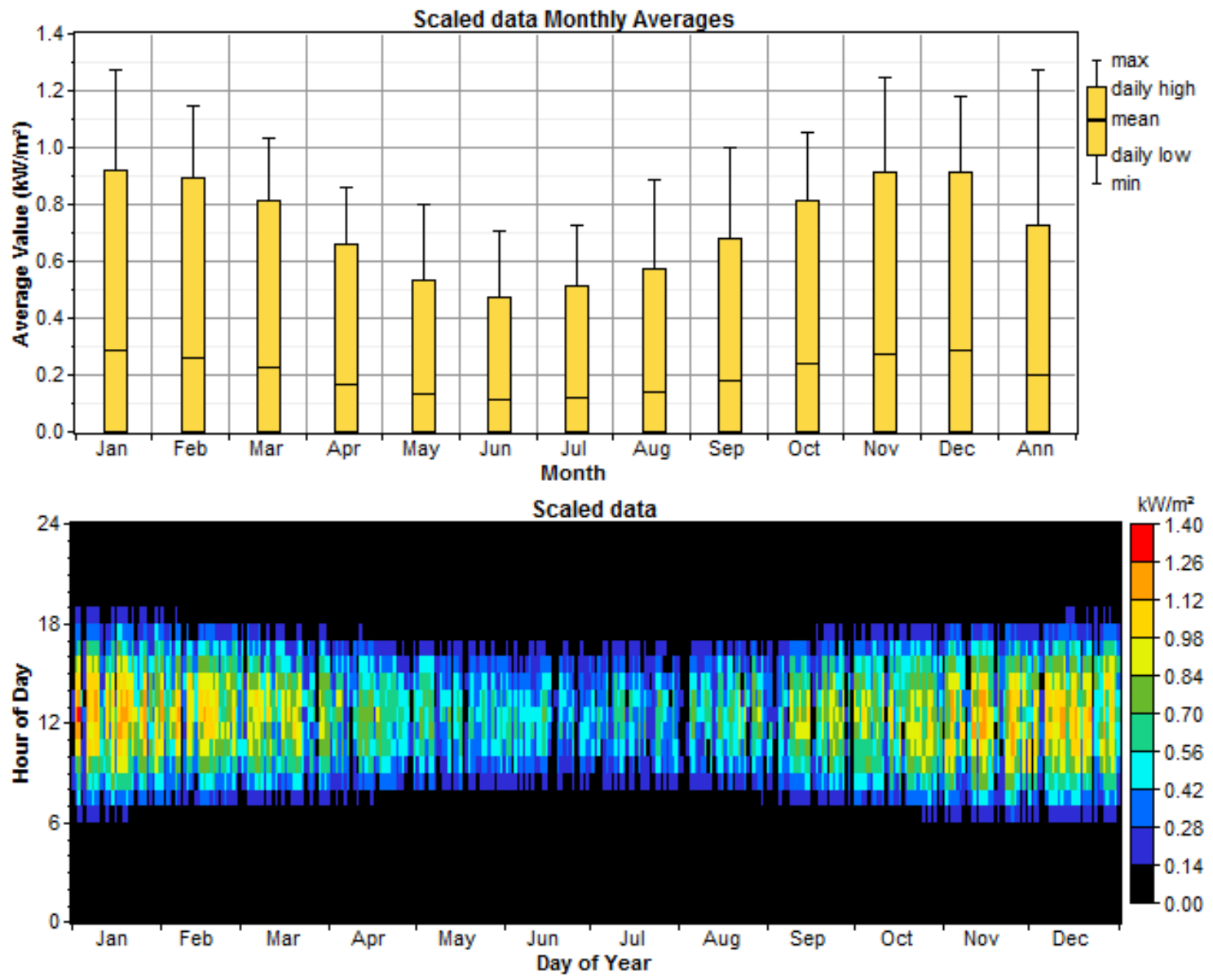

Figure 5. Availability of solar energy obtained by Homer with the databases of NASA

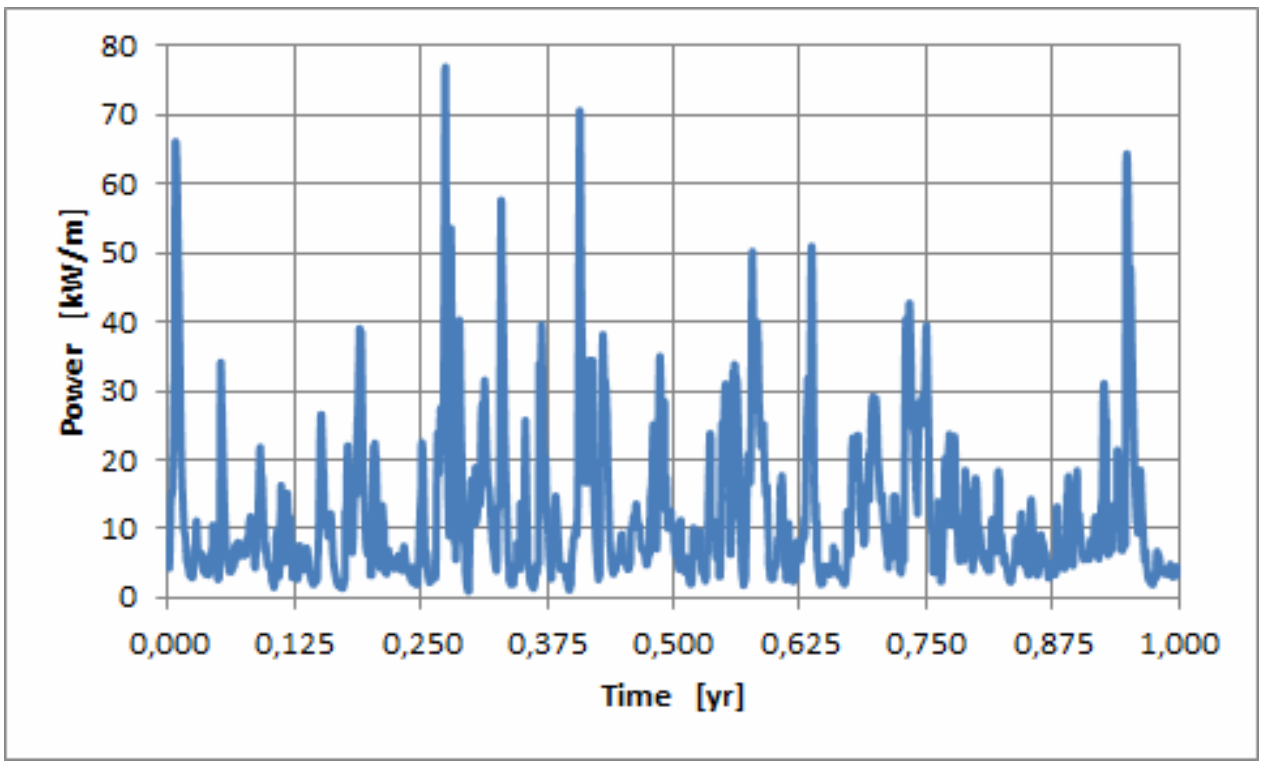

Figure 6. Data series for the wave energetic potential available in the location of the case study

Additionally, these simulations were also repeated to 7,500 $\$ / \mathrm{kW}$ installed, 5,000 $\$ / \mathrm{kW}$ installed, 3,000 $\$ / \mathrm{kW}$ installed, 2,000 $\$ / \mathrm{kW}$ installed and $1,000 \$ / \mathrm{kW}$ installed for capital cost of wave power plant, always with $80 \%$ of this for replacement costs and $5 \%$ of this for annual operation and maintenance costs. Finally, the plant was considered with two meters wavefront harnessed and efficiency $40 \%$. All results are presented in Reference [21]. 

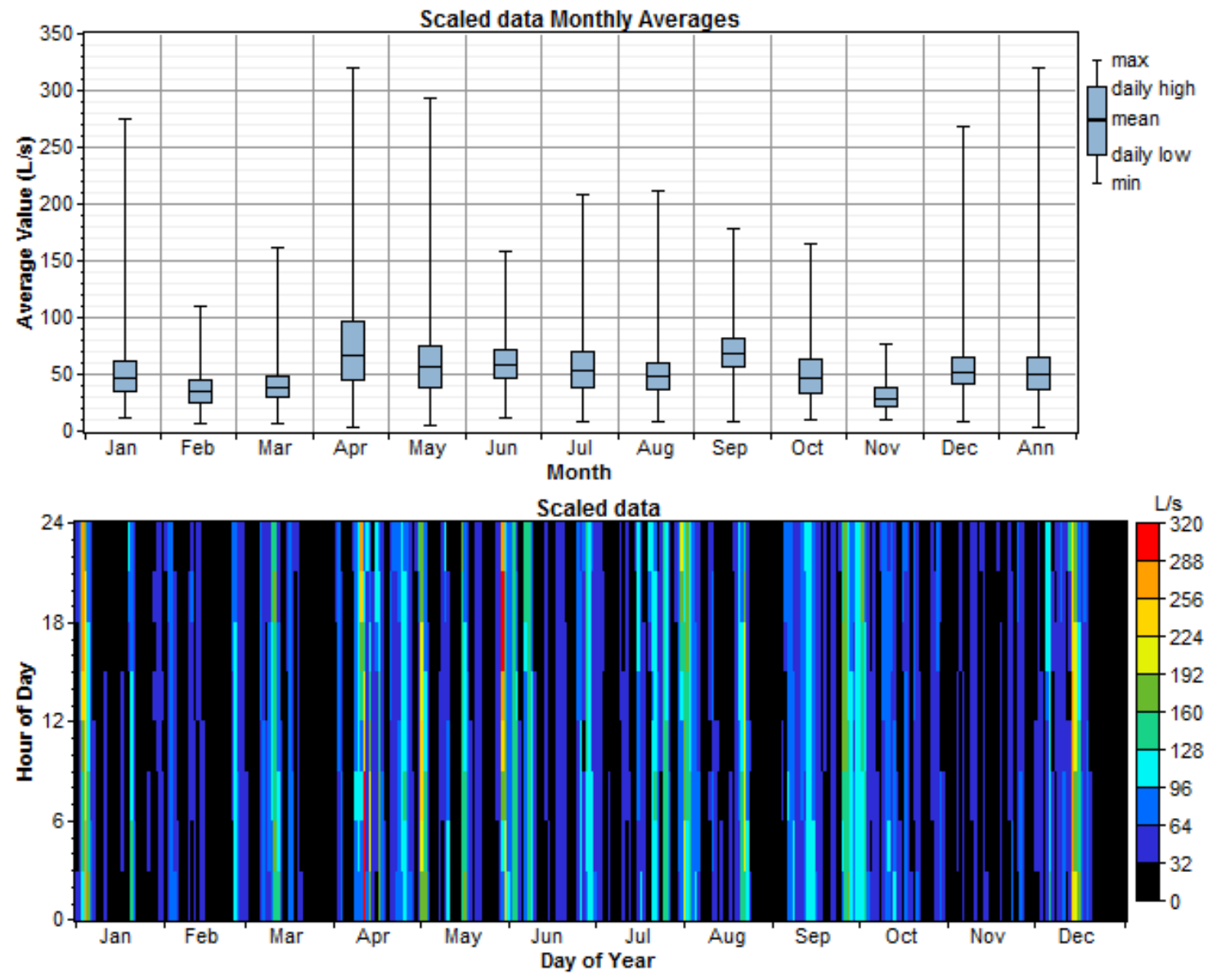

Figure 7. Data for wave energetic potential on-site of the case study, manipulated for Homer

Figure 8 reproduces the optimizations space for the system of Figure 3(a) even without the addition of ocean wave power plant. This result is also valid for the capital cost of the plant over U.S. $\$ 7,000$ per $\mathrm{kW}$ installed, without solutions in optimization space that include wave power plant.

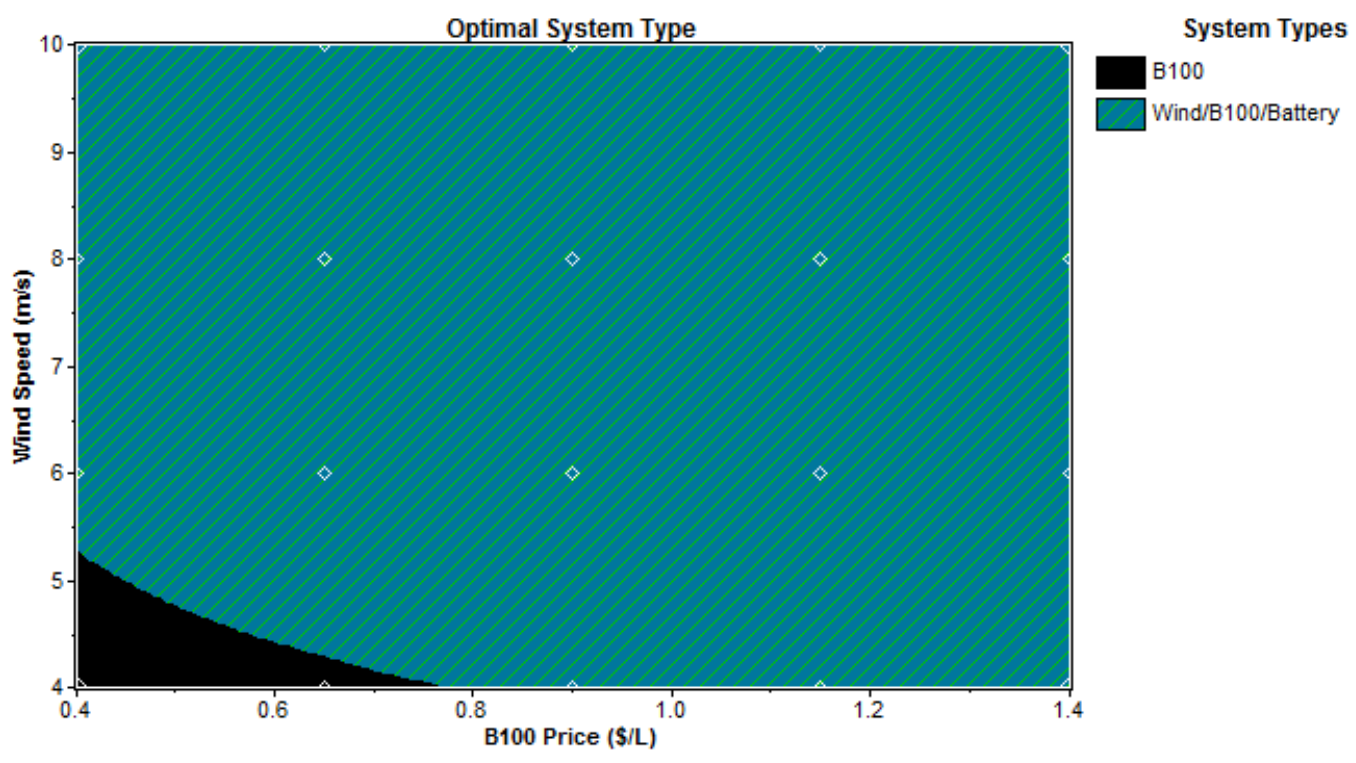

Figure 8. Simulation results with the system of the Figure 3 (a)

Figures 9, 10, 11 and 12 show the optimization spaces for the system of Figure 3(b) respectively with US\$ $5,000 / \mathrm{kW}$ installed, US\$ $3,000 / \mathrm{kW}$ installed, US\$2,000/kW installed and US\$ $1,000 / \mathrm{kW}$ installed. 
In these figures, where it is written "Hydro", should read "Wave". The area corresponding to solutions that include wave power plants appear in the lower right corner of the optimization space, where wind speeds are lower and biodiesel costs higher.

In Figure 9, the brown area corresponds to systems containing wave power plant and biodiesel generator set and the blue area with green stripes corresponds to systems composed of wave power plant, biodiesel gen set, wind turbines and batteries. These two areas will grow in the following figures, as the cost of installation is decreasing. The Figure 12 is dominated by these two areas, meaning that all solutions include wave power plants.

The results indicate that for a capital cost of US\$2,000/kW installed for converting wave energy, only the systems subject to higher wind speeds do not include wave power plants. For cost of US\$1,000/kW installed for converting wave energy, all solutions include wave power plants.

Obviously, more studies are needed to evaluate the relationship between dimensions of the wave power plants, their efficiency and capital costs. But these results already show the potential use of Homer as a tool for evaluation of feasibility of systems including wave energy converters.

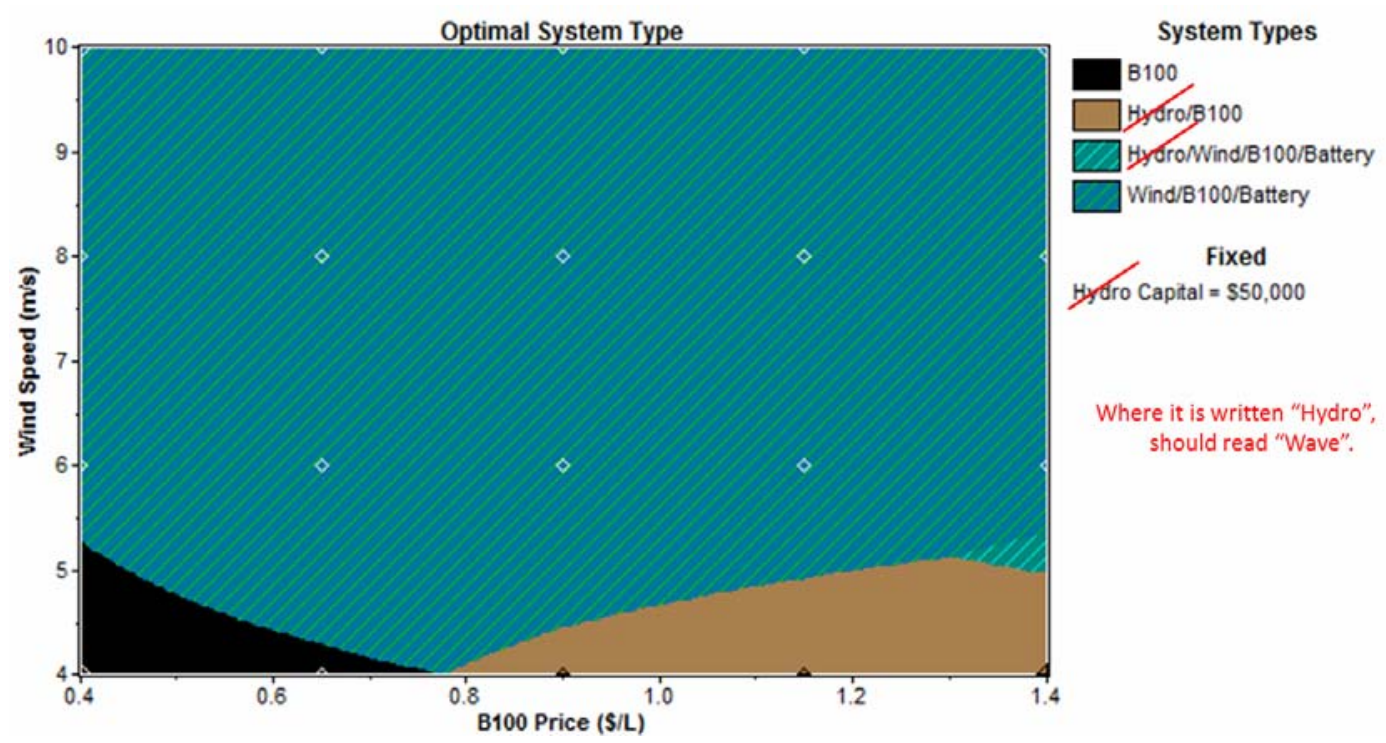

Figure 9. Simulation results with the system of the Figure 3 (b) with capital costs for wave power plant equal to US\$5,000/kW installed

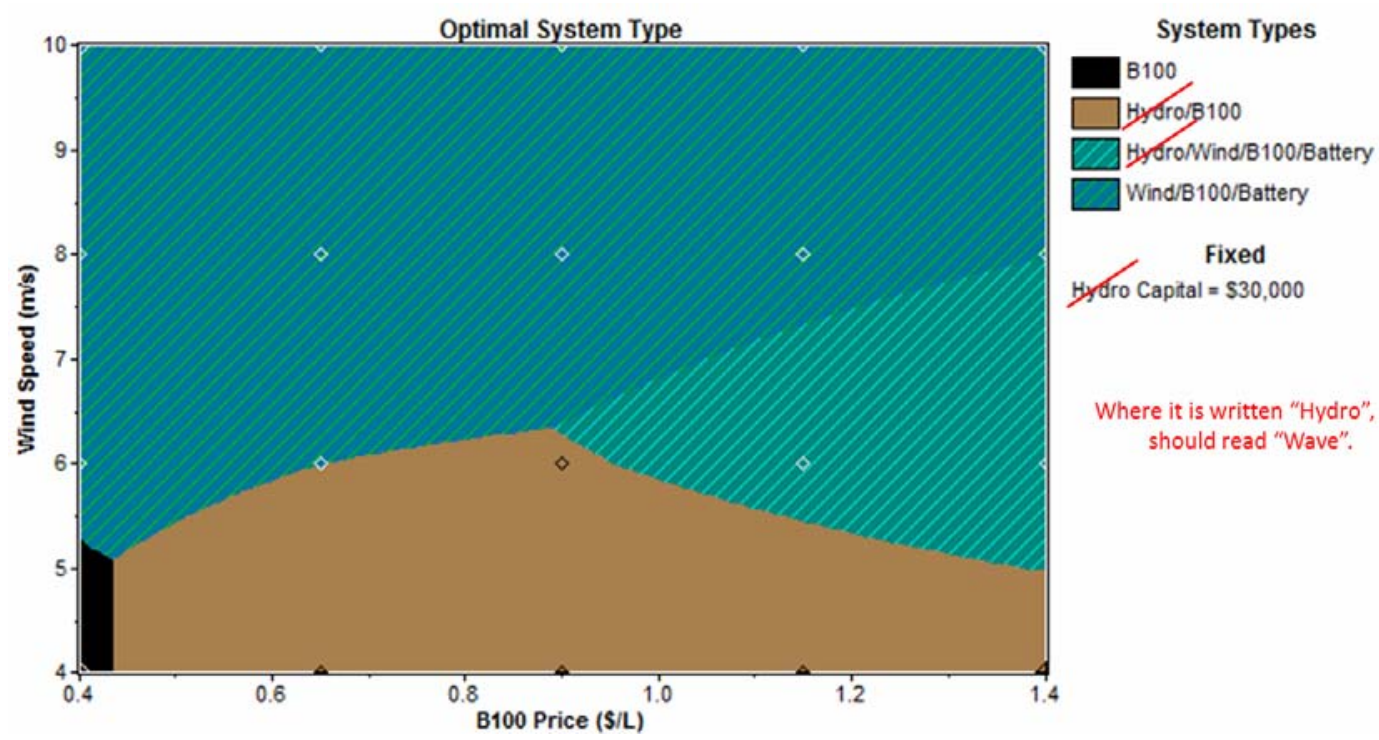

Figure 10. Simulation results with the system of the Figure 3 (b) with capital costs for wave power plant equal to US\$3,000/kW installed 


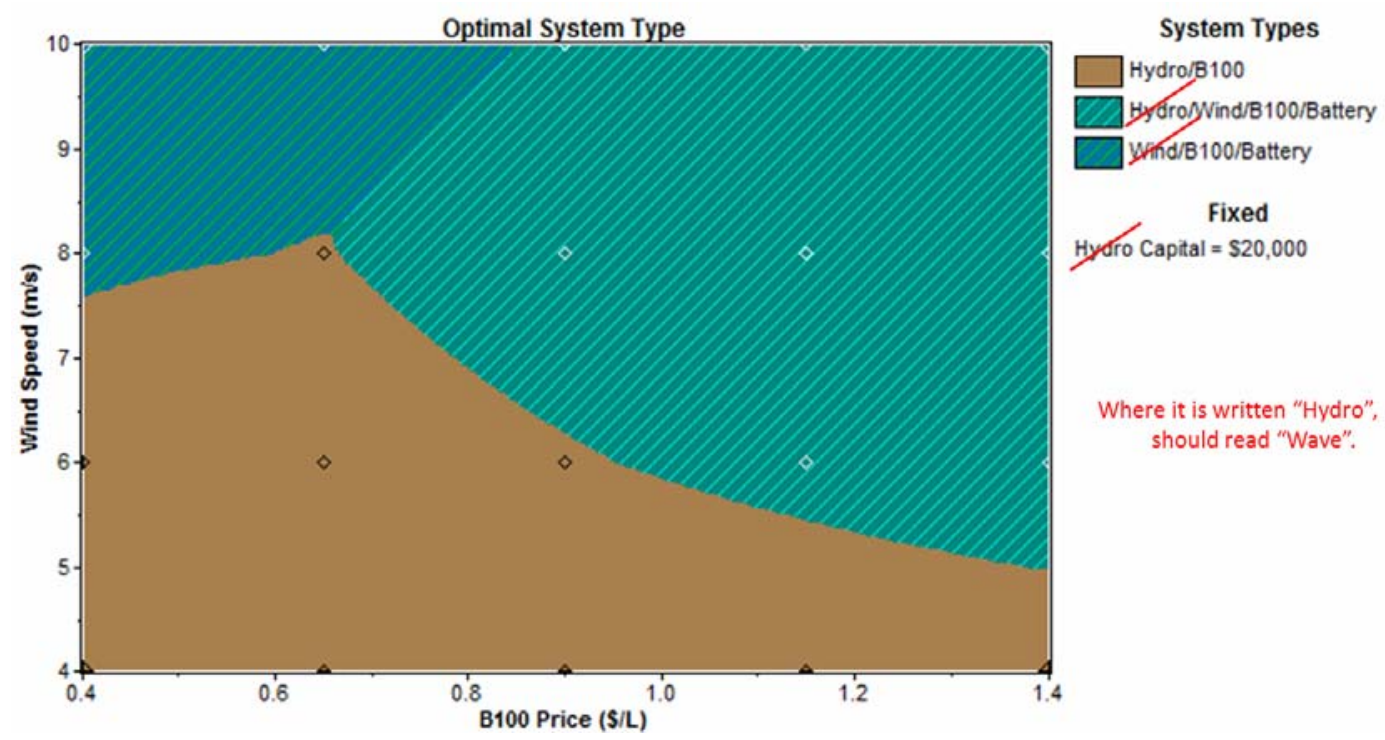

Figure 11. Simulation results with the system of the Figure 3 (b) with capital costs for wave power plant equal to US\$2,000/kW installed
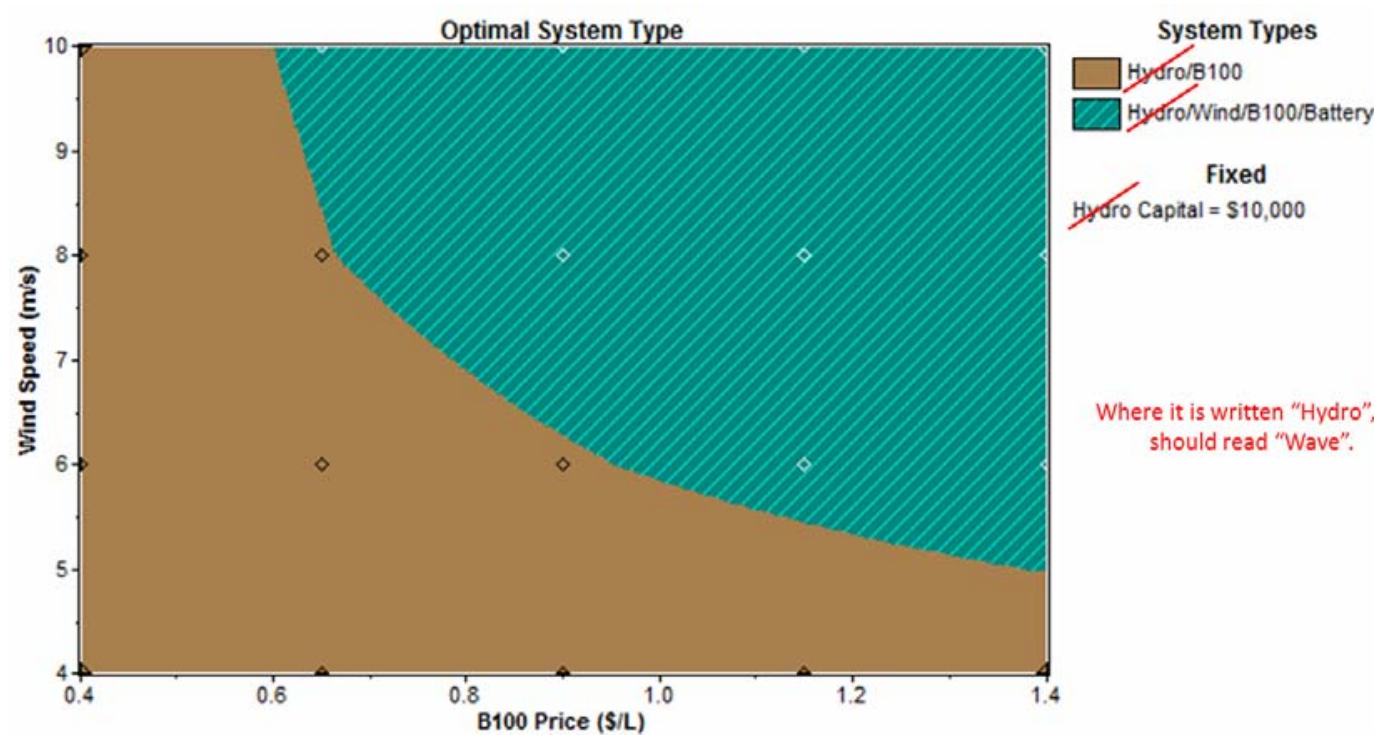

should read "Wave".

Figure 12. Simulation results with the system of the Figure 3 (b) with capital costs for wave power plant equal to US\$ $1,000 / \mathrm{kW}$ installed

\section{Final remarks}

This paper has presented and discussed the use of software Homer for simulating ocean wave power plants. As there is no model for this type of power plant, was proposed to adapt the model of hydroelectric power plants. A case study allowed the discussion of some initial results considering the inclusion of an ocean wave power plant in a wind biodiesel hybrid system.

Homer can be applied in the simulation of any device configuration for converting wave energy. The case study considered an ocean wave power plant exploring two meters of wave front, with $40 \%$ efficiency. The results indicated that all the solutions of the optimization space will include ocean wave power plants, when the installation cost to be US\$ 1,000 per $\mathrm{kW}$ installed.

\section{Acknowledgements}

This work was developed as a part of research activities on renewable energy developed at the Instituto de Pesquisas Hidráulicas, Universidade Federal do Rio Grande do Sul. The authors acknowledge the support received by the institution and the receptivity found among the owners of the small farm considered in this study, which do not want her identity disclosed. 


\section{References}

[1] Bahaj, A.S. (2011) Generating electricity from the oceans. Renewable and Sustainable Energy Reviews, v.15, p.3399-3416.

[2] Falcão, A.F.O. (2010) Wave energy utilization: a review of the technologies. Renewable and Sustainable Energy Reviews, v.14, p.899-918.

[3] Falnes, J. Lovseth, J. (1991) Ocean wave energy. Energy Policy, v.19, n.8, p.768-775.

[4] Lambert, T.W. Gilman, P. Lilienthal, P.D. (2005) Micropower system modeling with Homer. In: Farret, F.A. Simões, M.G. Integration of Alternative Sources of Energy, John Wiley \& Sons, p.379-418. ISBN 0471712329.

[5] Lilienthal, P.D. Lambert, T.W. Gilman, P. (2004) Computer modeling of renewable power systems. In: Cleveland, C.J. (ed.) Encyclopedia of Energy, Elsevier, v.1, p.633-647. NREL Report CH-710-36771.

[6] Lilienthal, P.D. Lambert, T.W. Gilman, P. (2011) Getting started guide for Homer Legacy (version 2.68). Homer Energy, Boulder, CO; National Renewable Energy Laboratory (NREL) of the USDOE, Golden, CO; 28p.

[7] Homer Energy (2009) Software HOMER, version 2.68 beta, The Micropower Opyimization Model. Available at www.homerenergy.com.

[8] Polinder, H. Scuotto, M. (2005) Wave energy converters and their impact on power systems. International Conference on Future Power Systems, 9p.

[9] Anagnostopoulos, J.S. Papantonis, D.E. (2008) Simulation and size optimization of a pumped storage power plant for the recovery of wind farms rejected energy. Renewable Energy, v.33, p.1685-1694.

[10] Beluco, A. Souza, P.K. Krenzinger, A. (2008) A dimensionless index evaluating the time complementarity between solar and hydraulic energies, Renewable Energy, v.33, p.2157-2165.

[11] Beluco, A. Souza, P.K. Krenzinger, A. (2012) A method to evaluate the effect of complementarity in time between hydro and solar energy on the performance of hybrid hydro PV generating plants. Renewable Energy, v.45, p.24-30.

[12] Twidell, J. Weir, T. (2006) Renewable Energy Resources. Taylor and Francis, Great Britain, 2nd edition.

[13] Izadparast, A.H. Niedzwecki, J.M. (2011) Estimating the potential of ocean wave power resources. Ocean Engineering, v.38, p.177-185.

[14] Ortega, S. Osorio, A.F. Agudelo, P. (2013) Estimation of the wave power resource in the Caribbean Sea in areas with scarce instrumentation. Case study: Isla Fuerte, Colombia. Renewable Energy, v.57, p.240-248.

[15] Google Inc. (2013) Google Maps. Available at maps.google.com.

[16] Ponticelli, F.A. Beluco, A. (2014) Inclusion of biodiesel and PV modules in a wind diesel hybrid system supplying electrical loads on a small farm. International Journal of Renewable Energy Technology, v.5, n.3, p.229-250.

[17] Caetano Branco Company (2012) Branco Generators Set, www.branco.com.br/us. Accessed on December 28, 2012.

[18] Cell Energy International (2013). WES 5 Tulipo Wind Turbine. Available at cellenergyinternational.co.uk/pdf/WES5_Tulipo_brochure_ds1.pdf. Accessed on July 31, 2013.

[19] Assis, L.E. Beluco, A. Almeida, L.E.S.B. (2014) On the wave energy potential along the southern coast of Brazil. International Journal of Energy and Environment, v.5, n.1, p.59-66.

[20] Vision Battery (2013) Vision 6FM200D Model. Available at www.vision-battery.com. Accessed on Abril 02, 2013.

[21] Silva, J.S. Beluco, A. Almeida, L.E.B. (2013) Simulation results with Homer on the inclusion of an ocean wave power plant in a wind biodiesel hybrid system. Internal report. UFRGS, IPH. Available at www.beluco.net/reports/homer-wave-01.pdf. 


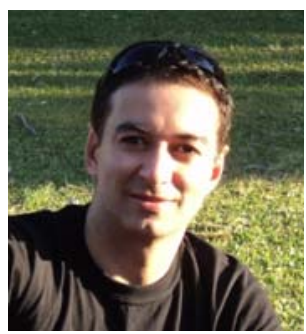

Jones Souza da Silva is Civil Engineer by Federal University of Rio Grande do Sul - UFRGS (2008), master of Water Resources and Environmental Sanitation by Institute of Hydraulic Research - IPH of UFRGS (2012). He has worked for 15 years in Canoas City in management, urban planning and transport areas. He is doctoral student at IPH - UFRGS. He has studied feasibility of generating energy systems based on ocean waves and his current research is on natural hazard management and resilience. E-mail address: joneswsilva@gmail.com

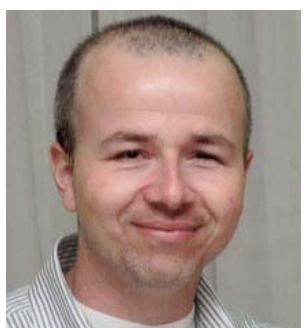

Alexandre Beluco is Doctor of Engineering, Civil Engineering and BS in Physics, and is a professor at the Institute of Hydraulic Research (IPH), UFRGS, and has activity as a researcher on renewable energy resources. He teaches courses on hydraulics and on design methods for undergraduate engineering and on planning and evaluation of experiments and on methods of design and research for the graduate course in water resources, for which also offers elective courses on natural resources and renewable energy. Currently, he serves as reviewer of Energy, Solar Energy and Renewable and Sustainable Energy Reviews and had an article recently cited by Renewable Energy Global Innovations.

E-mail address: albeluco@iph.ufrgs.br

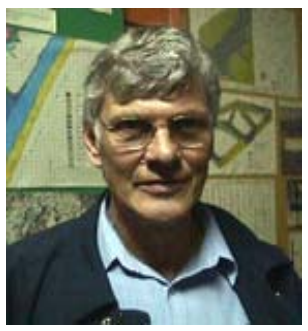

Luiz Emílio B. Almeida is graduated in Civil Engineering from the School of Engineering at Federal University of Rio Grande do Sul (1975), has specialization in Martime et Fluviale Ingenieur from Ecole Nationale des Travaux Publics de le Etat (1980) and Ph.D. in sedimentology from the University of Paris XI (Paris-Sud) (1983). Currently, he is a retired professor of the Institute of Hydraulic Research and researcher at Center for Coastal and Oceanic Geology Studies. Dr Almeida has experience in oceanography, with emphasis in physical oceanography, working on the following topics: protection of beaches, breaking waves, sediment transport. Unfortunately, he passed away a few months ago.

E-mail address: luiz.almeida@ufrgs.br 